\title{
EVALUASI PENERIMAAN KAS TERHADAP PENDAPATAN PADA PT.SURYAGITA NUSARAYA CARGO CABANG MAUMERE
}

\section{CASH REVENUE EVALUATION ON REVENUE IN PT.SURYAGITA NUSARAYA CARGO BRANCH MAUMERE}

\author{
Emilianus Eo Kutu Goo', Maria Nona Dince ${ }^{2}$, Walter Obon $^{3}$, \\ Magdalena Samosir ${ }^{4}$, Yoseph Darius Purnama Rangga ${ }^{5}$ \\ Universitas Nusa Nipa Maumere $1,2,3,4,5$ \\ emilyogowic@gmail.com ${ }^{1}$
}

\begin{abstract}
ABSTRAK
Sistem informasi akuntansi merupakan kumpulan berbagai sumber daya, baik itu manusia maupun peralatan, yang sengaja dirancang secara khusus dalam membantu pemrosesan untuk mengubah data keuangan dan data lainnya menjadi informasi. Penelitian ini bertujuan untuk mengetahui apakah sistem informasi akuntansi penerimaan kas atas pendapatan pengiriman paket di PT.Suryagita Nusaraya sudah memadai. Metode analisis yang digunakan adalah metode kualitatif deskriptif. Data penelitian diperoleh dari wawancara, observasi dan dokumentasi. Hasil penelitian menunjukkan bahwa fungsi, dokumen, pencatatan akuntansi, dan prosedur sistem informasi akuntansi penerimaan kas masih kurang memadai. Fungsi yang ada didasarkan pada teori, namun dalam menjalankan fungsinya tidak ada pemisahan tugas. Dokumen yang digunakan tidak lengkap karena perusahaan tidak membuat slip pembungkus. Pencatatan akuntansi dan prosedur penerimaan kas, telah dilaksanakan dengan baik. Hasil penelitian juga menunjukkan elemen utama pengendalian internal yang mendukung proses penerimaan kas belum terlaksana dengan baik.
\end{abstract}

Kata Kunci: Sistem Informasi Akuntansi, Penerimaan Kas

\section{ABSTRACT}

An accounting information system is a collection of various resources, both human and equipment, which are specially designed to assist processing to convert financial data and other data into information. This study aims to determine whether the accounting information system for cash receipts for package delivery revenue at PT.Suryagita Nusaraya is adequate. The analytical method used is descriptive qualitative method. Research data obtained from interviews, observation and documentation. The results showed that the functions, documents, accounting records, and cash receipts accounting information system procedures were still inadequate. The existing functions are based on theory, but in carrying out their functions there is no separation of duties. The documents used are incomplete because the company did not make a packing slip. Accounting records and cash receipt procedures have been implemented properly. The results also show that the main elements of internal control that support the cash receipt process have not been implemented properly.

Keywords: Accounting Information Systems, Cash Receipts 


\section{PENDAHULUAN}

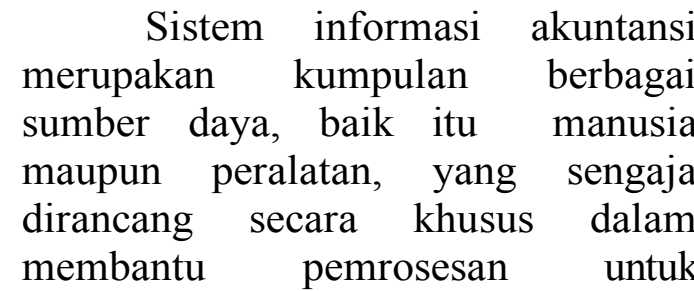
mengubah data keuangan dan data lainnya menjadi informasi. Sistem Informasi Akuntansi berfungsi sebagai informasi keuangan, pengawasan dan penunjang utama dalam menjalankan transaksi perusahaan. Oleh karena itu, sistem informasi akuntansi yang baik dan efektif sangatlah dibutuhkan dalam perusahan baik itu perusahaan jasa maupun perusahaan barang atau dagang.

Sistem Informasi Akuntansi yang baik harus bisa memberikan informasi tentang metode, teknik dan juga prosedur-prosedur dalam mencatat ataupun mengolah data akuntansi sehingga bisa menghasilkan pengedalian intern yang layak. Pengendalian intern harus bersumber dari organisasi yang tersuktur yang didalamnya terdapat praktek-praktek sehat, sumber daya manusia yang handal serta pembagian tugas yang jelas. Sistem perusahaan yang baik akan menghasilkan sistem informasi akuntansi yang baik pula karena sistem infromasi akuntansi memberikan peranan yang sangat penting dalam sebuah sistem. Sistem informasi akuntansi yang buruk akan memberikan informasi yang kurang handal terhadap sistem sehingga bisa menimbulkan potensi-potensi kerugian pada sistem.

PT. Suryagita Nusaraya Cargo merupakan perusahaan jasa yang bergerak di bidang pengiriman barang baik dalam negeri maupun luar negeri. Bentuk layanan yang dilakukan PT.Suryagita Nusaraya Cargo berupa pengiriman paket barang dan dokumen. Motivasi perusahaan ini lebih diutamakan kepada pelayanan jasa kepada masyarakat sehingga pencapian laba bukan menjadi prioritasnya. Akan tetapi, di sisi lain perusahaan juga memperhatiakn tingkat keuntungan yang ditawarkan kepada perusahaan. Unsur pengendalian internal terhadap penerimaan kas yang bersumber dari pelayanan jasa perlu diperhatikan dari manajemen. Pengendalian internal sangat penting karena memuat keputusan dan prosedur yang menjaga aktiva-aktiva agar tidak disalahgunakan, meyakinkan bahwa informasi yang diberikan benar akurat dan memastiak tentang peraturan peraturan seharunya dipatuhi. Dengan adanya sistem informasi akuntansi yang memadai pada sistem penerimaan kas, maka perusahaan dapat menghasilkan informasi yang berguna untuk kepentingan perusahaannya.

Pengendalian internal terhadap sistem informasi akuntansi akan mengurangi kemungkinan terjadinya kekeliruan dan penyelewengan, tetapi tidak menghilangkan kemungkinan bahwa hal tersebut tidak terjadi. Tidak hanya pengendalian internal yang dibutuhkan oleh perusahaan dalam proses penerimaan kas, tetapi fungsi penerimaan kas, dokumen penerimaan kas, catatan akuntansi penerimaan kas, dan jaringan prosedur penerimaan kas dibutuhkan juga oleh perusahaan sehingga dalam pelaksanaan penerimaan kas semua berjalan dengan baik dan perusahaan tidak mengalami penyimpangan dan kerugian. Menurut Mulyadi (2013), penerimaan kas adalah transaksi yang sering terjadi yang berhubungan dengan uang yang masuk dalam perusahaan. Penerimaan kas merupakan transaksi 
yang sering terjadi dalam perusahaan yang berkaitan dengan uang masuk dan terjadi selama perusahaan tersebut masih beroperasi.

Dalam PT.Suryagita Nusaraya Cargo sistem informasi penerimaan kas sudah dijalankan dengan baik, namum dalam menjalankan fungsifungsi penerimaan kas masih dijalankan secara rangkap, yaitu satu bagian menjalankan lebih dari satu fungsi. Hal tersebut dapat menyebabkan unsur kehatian-hatian tidak diperhatikan, sehingga sering terjadi kesalahan dalam proses pencatatan dan proses input.

Penelitian oleh Pasaribu (2017) tentang Sistem Informasi Akuntansi Penerimaan dan Pengeluaran Kas memberikan hasil bahwa proses pencatatan transaksi di PT. Putra Mulia Perdana masih digunakan secara manual. Sistem komputerasisasi belum digunakan dalam proses pencatatan. Pencatatan laporan arus kas, laporan laba rugi dan laporan neraca dibuat secara manual dan tanpa program akuntansi. Belum adanya pembagian tugas yang jelas di bagian keuangan seperti finance dan accounting juga belum ada. Seorang karyawan masih dibebankan dengan banyak pekerjaan yaitu mulai dari penerimaan kas, pengeluaran kas, pencatatan serta membuat laporan keuangan bulanan yang akan dilaporkan setiap bulannya kepada pimpinan.

Hasil penelitian Sanjaya \& Siagin (2016) menunjukkan bahwa penerimaan kas pada PT. JBA Indonesia yang bergerak dibidang penjualan jasa berasal dari biaya administrasi kendaraan yang dimenangkan dan fee seller dari jumlah unit yang terjual. Pengendalian internal pada sistem informasi akunansi penerimaan kas di
PT. JBA Indonesia sudah sangat baik dan efektif karena setiap transaksi yang dicatat sesuai dengan nilai nominal yang ada.

Penelitian oleh Gracia et al, (2016) pada PT. PLN (PERSERO) Area Manado bahwa sistem informasi akuntansi terhadap siklus pendapatan sudah sangan baik dan masih membutuhkan pengembangan pada infrastruktur teknologi informasi terkomputerisasi online, sehingga dapat secara langsung terhubung ke kantor pusat.

Hasil penelitian Mukjizatiah \& Arisan (2016) tentang Analisis Sistem Informasi Akuntansi Penerimaan dan Pengeluaran Kas pada PT. Mardiatama Konstruksi Palembang bahwa sistem informasi penerimaan dan pengeluaran kas belum dijalankan secara efektif. Laporan keuangan tidak jelas dan terjadi selisih pencatatan bukti fisik dan pembukuan. PT. Mardiatama Konstruksi Palembang dalam kegiatan operasionalnya kurang memperhatikan sistem informasi akuntansi yang menunjang kegiatan operasional perusahaan. laporan keuangan mashi menggunakan sistem secara manual.

Berdasarkan beberapa kajian empiris tersebut, dapat disimpulkan bahwa dengan menerapkan sistem informasi akuntansi penerimaan kas yang baik dan efektif, proses penerimaan kas dapat berjalan lancar. Hal tersebut didukung oleh adanya fungsi penerimaan kas, pencatatan transaksi, penggunaan infrastruktur yang baik. Oleh kerena itu, berdasarkan masalah, kajian teoritis dan kajian emipiris diatas maka peneliti melakukan kajian ualng tentang evaluasi penerimaan kas terhadap pendapatan dengan obyek penelitian di PT.Suryagita Nusaraya 
Cargo Cabang Maumere.

\section{METODE PENELITIAN}

Penelitian ini menggunakan penelitian kualitatif deskriptif. Paradigma pengetahuan yang dilandasi pandangan konstrukvisme berupa makna jamak atas pengalaman individual, makna yang dibangun karena sosial dan historis dengan tujuan untuk pengembangan suatu teori ataupun pola harus ada dalam penelitian kualitatif. Paradigma tersebut harus menjadi paradigma primer dalam penelitian kualitatif. Penelitian ini untuk mendeskripsikan kondisi secara alamiah secara keseluruhan tentang pelaksanaan dan prosedur penerimaan kas yang sudah digunakan di PT. Suryagita Nusaraya Cargo Cabang Maumere.

Dalam penelitian kualitatif kehadiran peneliti merupakan instrumen kunci agar data yang diperlukan dalam penelitian berupa prosedur penerimaan kas dan juga pendapatan pada PT. Suryagita Nusaraya Cargo Cabang Maumere bisa diperoleh.

Lokasi penelitian adalah PT. Suryagita Nusaraya Cargo Cabang Maumere. PT. Suryagita Nusaraya Cargo Cabang Maumere ini beralamat di Jln. Adisupcipto Pensip, Kelurahan Waioti Kecamatan Alok Timur Kabupaten Sikka.

Penelitian ini menggunakan data kualitatif yaitu penyajian data secara deskriptif atau berupa uraian yang diperoleh dari PT. Suryagita Nusaraya Cargo Cabang Maumere.

Sumber data pada penelitian ini berupa data primer. Data Primer berupa wawancara dan observasi langsung pada Bagian Administrasi PT.Suryagita Nusaraya Cargo Cabang Maumere. Bagian administrasi membantu memberikan informasi mengenai prosedur pelaksanaan penerimaan kas dan bukti-bukti transaksi penerimaan kas dari pengiriman paket yang ada di PT. Suryagita Nusaraya Cargo Cabang Maumere secara khusus dan terperinci.

Wawancara semi terstruktur merupakan teknik wawancara yang digunakan dalam penelitian ini dengan harapan informan lebih terbuka dalam menyampaikan pendapat atau ide terhadap permasalahan yang diangkat dalam penelitian. Wawancara dilakukan agar data tentang pelaksanaan penerimaan kas di PT. Suryagita Nusaraya Cargo Cabang Maumere yang berhubungan dengan prosedur penerimaan kas, fungsi penerimaan kas, dokumen penerimaan kas, catatan akuntansi penerimaan kas, jaringan prosedur penerimaan kas dan pengendian penerimaan kas dapat diperoleh oleh peneliti.

Teknik observasi yang digunakan dalam penelitian ini berupa observasi partisipasi aktif, yaitu jenis observasi yang mengikuti apa yang dilakukan oleh narasumber, meskipun belum sepenuhnya lengkap. Observasi dilakukan agar bisa diperoleh data tentang prosedur penerimaan kas yang dimulai dari observasi terhadap pendapatan pengiriman paket pada PT.Suryagita Nusaraya Cargo Cabang Maumere.

Perekaman data hasil wawancara, observasi atau hasil analisis tentang fungsi penerimaan kas, jaringan prosedur penerimaan kas, catatan akuntansi penerimaan kas, dokumen penerimaan kas dan pengendalian internal menggunakan teknik dokumentansi.

Aktivitas dalam analisis data kualitatif berupa reduksi data dan penyajian data harus dilakukan secara 
interaktif dan secara terus- menerus sampai jenuh agar bisa memperoleh kesimpulan.

1. Data Reduction (Reduksi Data). Data hasil wawancara dan observasi tentang sistem informasi akuntansi penerimaan kas dan pendapatan pengiriman paket pada PT. Suryagita Nusaraya Cargo dilakukan reduksi data dengan cara merangkum, memilih poin-poin pokok agar sesuai dengan tema dan polanya. Data yang tidak dibutuhkan dalam penelitain dibuang.

2. Data Display (Penyajian Data). Langkah kedua dalam analisis data setelah data direduksi, adalah mendisplaykan data. Data disajikan dalam bentuk uraian singkat berupa teks naratif, bagan dan hubungan antara kategori tentang sistem informasi akuntansi penerimaan kas.

3. Conclusion Drawing / Verfication (Verifikasi dan Penegasan Kesimpulan). Langkah terakhir setelah data direduksi dan disajikan adalah penarikan kesimpulan dan verifikasi. Pada tahap kesimpulan data-data yang diperoleh harus benar-benar valid dan konsisten agar kesimpulan yang dihasilkan bersifat kredibel ( dapat dipercaya). Tentunya pengecekan validitas data berupa perpanjangan pengamatan, meningkatkan ketekunan dalam pengamatan, triangulasi, menganalisis kasus-kasus negatif serta menggunakan bahan refrensi sebagai alat bantu pembuktian data yang ditemukan mesti dilakukan berulang - ulang sehingga sampai pada tahap terkahir yaitu berupa kesimpulan.

\section{HASIL DAN PEMBAHASAN Penyajian Data}

Penyajian data dalam penelitian ini dilakukan dengan wawancara langsung pada narasumber atau informan yaitu Bagian Administrasi. Peneliti bertanya mengenai fungsi - fungsi yang saling berhubungan dalam sistem informasi akuntansi penerimaan kas pada perusahaan? Jawaban yang diberikan oleh Bagian Administrasi bahwa "Fungsi penerimaan kas yang dijalankan dalam perusahaan adalah fungsi penjualan (loket), fungsi kas, fungsi pengiriman dan fungsi akuntansi".

Peneliti bertanya lebih lanjut, bagaimana fungsi-fungsi penerimaan kas itu dijalankan dan Bagian Adminitrasi menjawab, "Dalam menjalankan fungsi penerimaan kas yang ada bagian penjualan menerima barang yang hendak dikirim oleh bagian pengiriman. Kemudian barang yang akan dikirim tersebut ditimbang oleh bagian penjualan ataupun pengirim, di booking dan akan dibuatkan invoice (bukti atau faktur penjualan jasa) yang didalamnya tertera total pembayaran dan bagian penjualan menerima pembayaran dari pengirim sesuai dengan total pembayaran yang ada pada invoice dan bagian penjualan akan menyerahkan total pembayaran beserta dengan invoicenya kepada bagian kas dan bagian kas akan menyerahkan barang atas invoice ke bagian pengiriman untuk di kirim dan diterima oleh bagian maskapai (pihak yang akan menerima barang untuk diterbangkan)".

Peneliti bertanya, dalam proses penerimaan juga pasti semuanya berkaitan dengan keuangan, fungsi apa yang dijalankan berkaitan dengan pengelolaan keuangan dan Bagian 


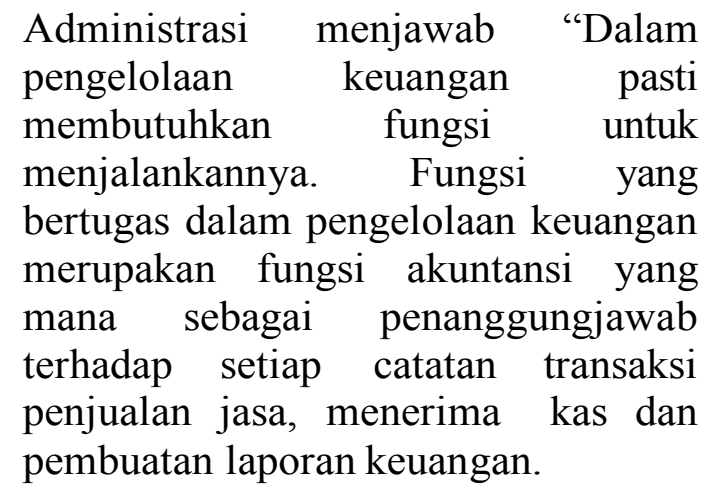

Peneliti bertanya, pada saat menjalankan fungsi penerimaan kas apakah setiap bagian menjalankan fungsinya masing-masing dan Bagian Administrasi menjawab,“ Dalam menjalankan tugas setiap fungsi sudah menjalankan fungsinya masingmasing, tetapi dalam pelaksanaannya dijalankan dengan tugas rangkap atau satu fungsi bisa menjalankan lebih dari satu tugas. Seperti dalam perusahaan, bagian kas atau kasir dirangkap dengan bagian akuntansi serta bagian penjualan dirangkap dengan bagian pengiriman".

Peneliti bertanya lebih lanjut tentang dokumen apakah yang digunakan perusahaan dalam sistem informasi akuntansi peneriman kas? Bagian Administrasi menjawab, " Dokumen penerimaan kas yang digunakan adalah faktur penjualan jasa (bukti terima kiriman) yang mana dalam perusahaan disebut dengan invoice (lembar faktur), yaitu bagian penjualan yang akan mengeluarkanya setelah barang ditimbang dan dibooking dan melakukan pembayaran. Setelah invoice dibuat dan ditandatangani oleh bagian penjualan dan pengirim akan diserahkan bukti penerimaan kas kepada bagian kas dan bagian kas ke bagian pengiriman. Dalam perusahaan juga melakukan penyetoran ke bank dengan bukti setor bank berupa slip penyetoran yang disediakan oleh bank, penyetoran dilakukan per hari.
Sedangkan slip pembungkus tidak digunakan karena pengirim sudah melakukan packing berdasarkan ketentuan SOP (Standar Operasional Order) jadi perusahaan menerima barang yang siap untuk di kirim lewat Maskapai (petugas pengirim ) dan barang siap untuk dikirim".

Peneliti bertanya lagi tentang catatan - catatan yang berhungan dengan sistem informasi akuntansi penerimaan kas perusahaan? Bagian Administrasi menjawab, "Catatan Akuntansi yang digunakan adalah jurnal umum dan jurnal penerimaan kas. Semua transaksi yang sudah dicatat dalam jurnal umum dan jurnal penerimaan kas akan di masukan ke dalam buku besar sehingga bisa dibuat menjadi laporan keuangan. Semua proses sudah dijalankan secara terkomputerisasi atau menggunakan aplikasi".

Peneliti bertanya lanjut tentang bagaimana jaringan prosedur sistem informasi akuntansi penerimaan kas perusahaan? Bagian Adminitrasi menjawab," Di dalam menjalankan prosedur penerimaan kas ada prosedur penjualan yang mana pengirim datang ke perusahaan, menimbang barang dan perusahaan mengisi PTI (Surat Penjelasan/Keterangan Isi Barang), pengirim menandatangani dan di booking oleh perusahaan dan akan keluar SMU (Surat Muatan Udara) atau kode booking baru dibuat invoice (faktur) dan baru dibayar".

Peneliti bertanya lebih lanjut mengenai prosedur penerimaan kas yang dijalankan dalam perusahaan? Bagian Administrasi menjawab,"Prosedur penerimaan kas dengan cara membuat invoice (faktur), menerima pembayaran harga barang atau tarif jasa dan memberikan tanda pembayaran kepada kasir dan diinput sedangkan dalam proses 
pencatatan penjualan jasa, penyetoran kas ke bank dan pencatatan ke buku besar dilakukan oleh bagian kasir yang merangkap sebagai bagian atau fungsi akutansi”.

Peneliti bertanya bagaimana unsur sistem pengendalian internal dalam sistem informasi akuntansi penerimaan kas perusahaan? Bagian Administrasi menjawab, "Dalam perusahaan struktur organisasi mempunyai tiga bagian yaitu penanggung jawab sementara, bagian operasional dan bagian administrasi".

Peneliti bertanya lebih lanjut, apa wewenang atau prosedur pencatatan dalam organisasi dan Bagian Administrasi menjawab, "Penanggung jawab sementara berwewenang untuk mengontrol penjualan atau penerimaan barang berjalan lancar atau tidak, bagian operasional melakukan penjualan, pengiriman, penerimaan dan ada penerimaan delivery dan bagian administrasi berwewenang dalam pembuatan laporan keuangan".

Peneliti bertanya lebih lanjut lagi, apakah dalam pelaksanaan kerja sehat setiap bagian melakukan fungsi masing- masing dan apakah pegawai dalam perusahaan merupakan pegawai yang berkualitas dan Bagian Administrasi menjawab, "Dalam pelaksanaan kerja pada setiap fungsi masih dilakukan secara rangkap dan pegawai dalam perusahaan merupakan pagawai yang berkualitas karena dilalui dengan proses rekruitmen yang baik dan berbasis operasional".

\section{Data Reduction (Reduksi Data)}

1. Fungsi - fungsi yang saling berhubungan dalam sistem informasi akuntansi penerimaan kas pada perusahaan? Berdasarkan hasil wawancara, informan menyampaikan bahwa Fungsi penerimaan kas yang dijalankan dalam perusahaan adalah fungsi penjualan (loket), fungsi kas, fungsi pengiriman dan fungsi akuntansi".

2. Dokumen apakah yang digunakan perusahaan dalam sistem informasi akuntansi peneriman kas? Berdasarkan hasil wawancara, informan menyampaikan bahwa dokumen yang digunakan adalah faktur penjualan jasa (bukti terima kiriman), dalam perusahaan menyebutkan dengan invoice dan bukti setor bank, surat muatan udara (smu), penjelasan isi barang (pti).

3. Catatan akuntansi yang digunakan dalam penerimaan kas perusahaan? Berdasarkan hasil wawancara informan menyampaikan bahwa catatan akuntansi yang digunakan adalah jurnal penerimaann kas dan jurnal umum.

4. Bagaimana prosedur penerimaan kas dijalankan dalam perusahaan? Berdasarkan hasil wawancara informaan menyampaikan bahwa prosedur penerimaan kas dengan cara membuat invoice (faktur), menerima pembayaran harga barang atau tarif jasa dan memberikan tanda pembayaran kepada kasir dan diinput sedangkan dalam proses pencatatan penjualan jasa, penyetoran kas ke bank dan pencatatan ke buku besar dilakukan oleh bagian kasir yang merangkap sebagai bagian atau fungsi akutansi”.

5. Unsur pengendalian internal sudah diterapkan perusahaan secara baik? Berdasarkan hasil wawancara bahwa perusahaan telah menerapkan unsur 
pengendalian secara baik, meskipun dalam pelaksanaan tugas atau tanggungjawab masih dilakukan secara rangkap.

\section{Data Display (Penyajian Data) \\ Sistem Informasi Akuntansi Penerimaan Kas}

Berdasarkan hasil wawancara dan observasi oleh peneliti, ditemukan bahwa transaksi PT.Suryagita Nusaraya Cargo didominasi oleh penerimaan kas. Proses penerimaan kas yang dilaksanakan oleh perusahaan dalam proses manual dan terkomputerisasi. Penerimaan kas PT.Suryagita Nusaraya Cargo Maumere bersumber dari jasa penjualan yaitu pengiriman paket, dokumen atau delivery.

Dalam proses penerimaan kas prosedur penjualan yaitu pengirim datang ke perusahaan, menimbang barang dan pihak perusahaan mengisi PTI (Surat Penjelasan/Keterangan Isi Barang) yang terdiri dari tiga lembar yaitu warna putih untuk penerima atau tujuan(1), warna hijau muda untuk pengirim barang(2) dan warna merah muda untuk perusahaan sebagai arsip perusahaan(3).

Setelah perusahaan mengisi PTI pengirim menandatangani dan di booking oleh perusahaan dan perusahaan mengeluarkan SMU (Surat Muatan Udara) atau kode booking yang akan diserahkan pada bagian pengiriman dan diterima oleh bagian maskapai untuk barang diterbangkan.

Invoice dikeluarkan oleh perusahaan apabila SMU dan PTI sudah dinyatakan benar dalam pengisian. Invoice terdiri dari lima lembar yaitu warna putih untuk pengirim(1), warna merah untuk diserahkan kebagian pengiriman bersama barang(2), warna biru untuk bukti kas bagian adminitrasi atau bagian akuntansi(3) dan warna hijau(4) serta warna kuning(5) sebagai arsip perusahaan dan akan discan untuk dikirim ke kantor pusat dan setelah invoice dikeluarkan pengirim melakukan pembayaran. Invoice ditandatangani oleh pengirim dan diserahkan ke bagian pengiriman untuk selanjutnya diserahkan kepada bagian maskapai dan barang siap untuk diterbangkan. Faktur atau invoice akan diserahkan juga kepada pengirim sebagai bukti bahwa barang sudah dikirim dan sudah melakukan pembayaran. Apabila semua proses dari penjualan, pengiriman, pembayaran dan barang sudah diterbangkan maka penerimaan kas oleh bagian kas akan disetor ke bank dan bagian adminitrasi akan menginput transaksi ke dalam jurnal penerimaan kas atau jurnal khusus, lalu ke jurnal umum, buku besar dan membuat laporan keuangan untuk dilaporkan.

Proses penerimaan kas yang dilakukan oleh perusahaan sudah sangat baik, namun dalam menjalankan fungsi pada setiap bagian tidak dilakukan masingmasing. Setiap fungsi dijalankan secara rangkap yaitu satu bagian menjalankan fungsinya lebih dari satu fungsi. Berdasarkan teori Mulyadi (2013), dalam menjalankan fungsi penerimaan kas, setiap bagian harus menjalankan fungsinya masingmasing. Seperti halnya, dalam menjalankan fungsi kas dan fungsi akuntansi harus dipisahkan.

\section{Pengendalian Internal berdasarkan Sistem Informasi Akuntansi Penerimaan Kas}

Perusahaan tentunya membutuhkan pengendalian internal yang baik agar dalam pelaksanaan 
setiap proses dalam perusahaan berjalan dengan efektif. Pengendalian dalam perusahaaan sudah mencapai tujuan perusahaan berdasarkan dengan unsur-unsur pengendalian internal.

Unsur struktur organisasi dalam perusahaan terdiri dari tiga bagian yaitu penanggung jawab sementara, bagian administrasi dan bagian operasional. Setiap bagian mempunyai tugas masing-masing yaitu penanggung jawab sementara bertanggungjawab dalam mengontrol penjualan berjalan dengan baik atau tidak dan melakukan penyetoran kas ke bank, bagian operasional bertanggungjawab dalam penerimaan barang yang akan dikirim, menimbang, menerima pembayaran dan mengirim barang ke bagian maskapai dan bagian adminitrasi menerima kas yang telah di bayar, mencatat transaksi yang terjadi dan membuat laporan keuangan sehingga dalam pelaksanaan tugas dan tanggungjawab masih dilakukan rangkap atau setiap pegawai melakukan pekerjaan lebih dari satu tugas.

Unsur pelaksanaan kerja yang sehat dibuat sedemikian rupa agar mendukung tercapainya tujuan pengendalian internal. Dalam perusahaan pelaksanaan kerja sehat belum dijalankan dengan baik dikarenakan unsur kehati-hatian dalam perusahaan belum dijaga dengan baik. Hal tersebut disebabkan dalam menangani transaksi penerimaan kas, tidak ada sistem rolling antar pegawai, satu pegawai menjalankan transaksi dari awal sampai akhir. Pelaksanaan kerja sehat meliputi semua proses penerimaan kas yang dilakukan perusahaan, yaitu berawal dari penerimaan barang oleh bagian penjualan, bagian penjualan menyerahkan invoice ke bagian pengiriman dan bagian pengiriman menyerahkan invoice ke bagian kas untuk kepentingan pembayaran dan melakukan penyetoran ke bank dan bagian kas menyerahkan kembali ke bagian pengiriman untuk dikirim ke bagian maskapai untuk barang siap diterbangkan, setelah barang diterbangkan bagian pengiriman menyerahkan invoice ke bagian akuntansi untuk proses pencatatan transaksi penjualan jasa dan transaksi penerimaan kas dan membuat laporan keuangan. Dalam pelaksanaan kerja sehat juga, bagian administrasi atau bagian akuntansi bertugas sebagai bagian pengarsipan dokumen. Dokumen yang diarsipkan yaitu invoice, surat muatan udara dan pemberitahuan isi barang.

Proses pengarsipan sudah dilaksanakan dengan baik dan rapi, yaitu dokumen invoice terdiri dari lima lembar yaitu warna putih untuk pengirim(1), warna merah untuk diserahkan kebagian pengiriman yang akan diterima oleh maskapai(2), warna biru untuk bukti kas bagian adminitrasi(3) dan warna hijau(4) serta warna kuning untuk arsip perusahaan dan akan discan untuk dikirim ke kantor pusat dengan email kantor(5). Dokumen pemberitahuan isi barang terdiri dari beberapa jenis berdasarkan pihak airlines atau pihak ketiga yang tertera didalam slip pembungkus yang sudah dibuat oleh pengirim berdasarkan SOP (Standar Operasional Prosedur). Dalam perusahaan dokumen pemberitahuan isi barang terdiri dari Sriwijaya Air, Wings Air dan Garuda Indonesia dan setiap dokumen terdiri dari tiga bagian yaitu warna putih untuk tujuan (penerima)(1), warna hijau muda untuk pengirim barang(2) dan warna merah muda untuk perusahaan dan diarsipkan berdasarkan tanggal yang 
ada pada setiap dokumen pemberitahuan isi barang(3). Perusahaan juga menyampaikan bahwa karyawan merupakan unsur pokok dalam sebuah organisasi. Pegawai yang di rekrut oleh perusahaan merupakan calon karyawan yang berkualitas yaitu memiliki pendidikan, pengalaman dan ahklak yang baik. Proses dalam perekrutan karyawan terjadi apabila dari kantor pusat mengeluarkan surat perekrutan karyawan berdasarkan permintaan kepala cabang.

\section{Conclusion Drawing / Verfication (Verifikasi dan Penegasan Kesimpulan)}

Berdasarkan pembahasan diatas, sistem informasi akuntansi penerimaan kas sudah sesuai dengan teori yang ada.Terutama dalam prosedur penerimaan kas yang dijalankan sudah sangat baik karena fungsi-fungsi yang dijalankan sesuai dengan teori yaitu dari bagian penjualan ke bagian pengiriman, bagian pengiriman ke bagian penjualan, bagian penjualan ke bagian kas, bagian kas ke bagian pengiriman dan bagian akuntansi menerima semua penerimaan kas dan melakukan pencatatan serta membuat laporan keuangan. Tetapi dalam menjalankan tugas tersebut masih dilakukan secara rangkap. Untuk membantu dalam penerimaan kas dan proses pencatatannya, maka perusahaan menggunakan beberapa dokumen yang berkaitan dengan penerimaan kas.

Dalam penerimaan kas, perusahaan tidak menggunakan slip pembungkus untuk ditempelkan pada barang yang akan diikirim, karena semuanya sudah dibuat oleh pengirim sesuai dengan SOP (Standar Operasional Prosedur) namun hal tersebut dapat membuat kekeliruan dari pihak kantor cabang yang menerima, apabila kantor cabang lupa dalam menginput nomor slip atau kode pembungkus. Catatan akuntansi yang digunakan sudah sesuai dengan teori yang ada, yaitu menggunakan jurnal penerimaan kas terlebih dahulu sebelum menginput kedalam jurnal umum, buku besar dan pada akhirnya membuat laporan keuangan.

Pengendalian internal yang diterapkan belum sesuai dengan teori yang ada, karena dalam struktur organisasi dan dalam pembagian tugas dan wewenang atau tanggungjawab, pelaksanaan kerja yang sehat belum berjalan dengan baik. Hal tersebut disebabkan dalam perusahaan hanya memiliki tiga bagian dalam struktur organisasi yaitu penanggung jawab sementara, bagian operasional dan bagian administrasi dan dalam menjalankan tugasnya masih dijalankan secara rangkap dan akan menyebabkan unsur kehatian-hatian tidak diperhatikan karena seorang karyawan melaksanakan tugasnya dari awal sampai akhir, dalam hal ini pada bagian operasional menjalankan fungsi penjualan dan pengiriman sedangkan bagian admnistrasi menjalankan fungsi kas sebagai kasir dan fungsi akuntansi sebagai pembuat laporan keuangan. Sedangkan pegawai yang berkualitas sudah diterapkan dengan baik.

\section{PENUTUP \\ Kesimpulan}

Berdasarkan data yang diperoleh dari penelitian mengenai sistem informasi penerimaan kas terhadap pendapatan kiriman paket pada PT.Suryagita Nusaraya Cargo, dapat disimpulkan beberapa hal sebagai berikut:

Sistem informasi akuntansi 
penerimaan kas pada PT.Suryagita Nusaraya Cargo Maumere belum sepenuhnya memadai dan belum berdasarkan teori. Terdapat empat subsistem yang saling bekerja sama dalam menjalankan kegiatan penerimaan kas yaitu fungsi penerimaan kas, dokumen penerimaan kas, catatan akuntansi penerimaan kas dan jaringan prosedur penerimaan kas. Dalam menerapkan fungsi penerimaan kas, perusahaan sudah menjalankan dengan baik, namun dalam menjalankan fungsinya pada setiap bagian belum ada pemisahan tugas. Satu bagian menjalankan lebih dari satu fungsi. Berdasarkan hasil penelitian bagian kas (kasir) menjalankan fungsi penerimaan kas dari penjualan jasa merangkap sebagai bagian akuntansi yang berfungsi untuk mencatat transaksi penjualan jasa, transaksi penerimaan kas serta pembuat laporan keuangan. Subsistem dokumen belum diterapkan dengan baik karena perusahaan tidak membuat slip pembungkus. Slip pembungkus dibuat oleh pemilik barang berdasarkan SOP (Standar Operasional Prosedur). Catatan akuntansi yang terdiri dari jurnal penerimaan kas dan jurnal umum sudah diterapkan dan dijalankan dengan baik karena dalam perusahaan sudah memakai sistem terkomputerisasi. Jaringan prosedur yang membentuk sistem informasi akuntansi penerimaan kas sudah dijalankan dengan baik yaitu semua prosedur berjalan dengan lancar dan terarah.

Dalam penerimaan kas juga diterapkan pengendalian internal sehingga dapat menjaga seluruh harta kekayaan organisasi, memeriksa ketelitian dan kebenaran informasi akuntansi, meningkatkan efisiensi operasional perusahaan dan membantu kebijaksanaan manajemen yang telah ditetapkan. Pengendalian internal yang diterapkan oleh perusahaan belum semua unsur memadai karena belum mencapai tujuan pengendalian internal. Berdasarkan hasil penelitian, unsur pengendalian internal yang sudah diterapkan dengan baik yaitu struktur organisasi, sistem wewenang dan prosedur pencatatan dalam organisasi dan pegawai berkualitas sedangkan pelaksanaan kerja yang sehat belum dijalankan dengan baik, karena satu bagian masih menjalankan transaksi dari awal sampai akhir. Hal tersebut dapat menyebabkan unsur kehatihatian tidak dijaga dan dapat menghindari kecurangan dalam perusahaan.

Berdasarkan kesimpulan secara umum diatas, dapat disimpulkan secara khusus bahwa keempat subsistem dan unsur pengendalian internal belum semuanya memadai karena keempat subsistem yang diterapkan dalam perusahaan belum dapat bekerjasama dalam melaksanakan kegiatan penerimaan kas dan unsur pengendalian internal belum mampu mencapai tujuan pengendalian internal.

\section{Saran}

Berdasarkan kesimpulan dari hasil penelitian, terdapat dua subsistem penerimaan kas serta satu unsur pengendalian internal yang belum memadai dan belum diterapkan dengan baik oleh perusahaan. Oleh kerena itu penulis dapat memberikan saran-saran sebagai bahan pertimbangan dalam mengadakan suatu perbaikan yaitu sebagai berikut: 
Bagi PT.Suryagita Nusaraya Cargo Maumere

1. Untuk memenuhi subsistem fungsi penerimaan kas, sebaiknya dalam menjalankan fungsi bagian kas (kasir) dan bagian akuntansi harus ada pemisahan tugas. Hal tersebut dibuat agar bagian kas (kasir) hanya sebagai penerimaan kas dan bagian akuntansi sebagai pencatat transaksi dan pembuat laporan keuangan. Maka kegiatan penerimaan kas berjalankan dengan lancar tanpa ada kendala.

2. Untuk memenuhi subsistem dokumen penerimaan kas, sebaiknya slip pembungkus tidak dibuat oleh pemilik barang sekalipun dibuat berdasarkan SOP (Standart Operasional Prosedur) melainkan dibuat oleh perusahaan, sehingga tidak membuat kekeliruan apabila kantor pengirim barang tidak mencantumkan kode pembungkus atau nomor slip bagi kantor penerima barang dan dapat memudahkan perusahaan karena proses pencatatan dalam invoice dilakukan satu kali.

3. Untuk memenuhi pengendalian internal, sebaiknya pelaksanaan kerja harus dijalankan secara sehat, yaitu harus adanya roliing antar pegawai sehingga dapat melaksanakan berbagai tugas yang telah diberikan dengan baik, memeriksa kekurangan dalam pelaksanaan, menghindari kecurangan, terciptanya mekanisme saling mengendalikan antar fungsi secara maksimal dan dapat mencapai tujuan pokok pengendalian internal.

4. Berdasarkan hasil penelitian, dalam menjalankan fungsi pada setiap bagian perusahaan masih melakukan secara rangkap. Oleh karena itu, penulis berharap perusahaan dapat merekrut dua atau lebih karyawan untuk membantu proses penerimaan kas dalam perusahaan, karena dengan perkembangan perekonomian yang semakin maju jasa pengiriman dibutuhkan oleh masyarakat.

\section{Bagi Pihak Lain}

Pihak lain yang tertarik untuk melakukan penelitian di PT.Suryagita Nusaraya Cargo Maumere, sebaiknya membantu dalam melakukan penelitian seperti analisis dan perancangan, evaluasi penerapan sistem informasi akuntansi, sistem informasi akuntansi pengeluaran kas dan sebagainya.

\section{DAFTAR PUSTAKA}

Gracia, M., M., \& Tirayoh, V., Z. (2016). Evaluasi Penerapan Sistem Informasi Akuntansi Atas Siklus Pendapatan Pada PT. Pln (Persero) Area Manado. Jurnal EMBA: Jurnal Riset Ekonomi, Manajemen, Bisnis dan Akuntansi, 4(1).

Mukjizatiah, S., \& Arisman, A. (2016). Analisis Sistem Informasi Akuntansi Penerimaan dan Pengeluaran Kas Pada PT Mardiatama Konstruksi Palembang.

Mulyadi. (2013). Sistem Informasi Akuntansi. Jakarta: Salemba Empat.

Pasaribu, A.,M. (2017). Analisis Sistem Informasi Akuntansi Penerimaan Kas dan Pengeluaran Kas, 4(1), 45-76.

Sanjaya, H.,R \& Riduan, S. (2016). Analisis Sistem Informasi Akuntansi Penerimaan Kas dan Pengeluaran Kas, 2(1), 1-35. 